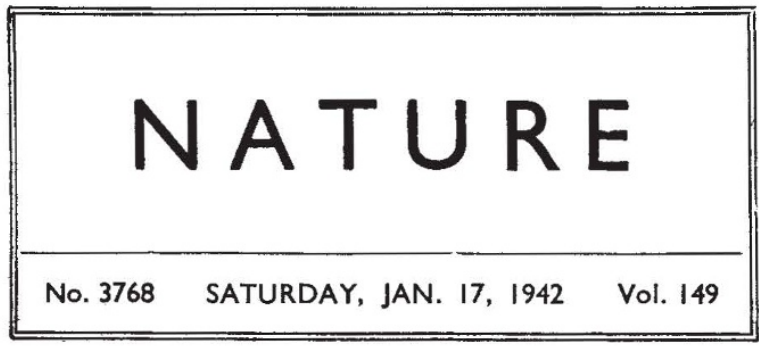

CONTENTS

The University of Orissa.

Page Teaching of Physiology. By Prof. Samson Wright . Impact of Inventions on People. By D. Caradog Jones Neurology for Students and Practitioners. By Dr. C. M. Hinds Howell

The Study of Lymph. By J. C. Mottram . . . Chromosome Chemistry and Gene Action. By Dr. C. D. Darlington, F.R.S. .

Edmond Halley, 1656-1742. By Dr. H. Spencer Jones, F.R.S. .

Conference on Science and the War Effort .

Obituaries :

Dr. H. Eltringham, F.R.S. By Prof. G. D. Hale Carpenter, M.B.E.

Mrs. Hertz. By Joan Thomson

News and Views.

Letters to the Editors:

Colour Measurement.-T. Smith, F.R.S., Dr. J. Guild, and R. Donaldson; Dr. V. G. W. Harrison

Pleistocene Raised Beaches on the West Coast of Morocco.-Abbé H. Breuil . .

Change of Pelage in the Stoat Mustela erminea L.The Hon. Miriam Rothschild . . . .

Klino-kinesis in Paramecium.-Dr. D. L. Gunn . .

Rapid Determination of Water in Animals and Plants. -A. G. Lowndes

Scientific Help for the Home Guard.-Captain John Langdon-Davies... . . .

Scientific and Industrial Research in Canada . .

New Spectrographic Observations of Peculiar Stars .

Use of Snowflake Replicas for Studying Winter Storms.

By Vincent I. Schaefer... . . . . .

Shoot Apex in Grasses and Cereals. By Dr. B. C.

Sharman . . . . . . . . .

Influence of Temperature and $\mathrm{pH}$ on the CIN Ratio of

Soils. By Prof. N. R. Dhar and N. N. Pant.

Editorial and Publishing Offices

MACMILLAN \& CO., LTD.,

ST. MARTIN'S STREET, LONDON, W.C.2

Telephone Number: Whitehall 883I

Telegrams : Phusis Lesquare London

Advertisements should be addressed to

T. G. Scott \& Son, Ltd., Three Gables, London Road, Merstham, Surrey Telephone: Merstham 316

The annual subscription rate is $£ 4100$, payable in advance, Inland or Abroad All rights reserved. Registered as a Newspaper at the General Fost Office

\section{THE UNIVERSITY OF ORISSA}

$\mathrm{D}$

URING the first decade of this century, mainly as the result of the recommendations of the Curzon Commission culminating in the Universities Act of 1904, the older Indian universities, Madras, Bombay, Calcutta and the Punjab, modified their examination requirements and effected fundamental alterations in the teaching in their affiliated colleges. Unfortunately, the university examinations in their various grades from the matriculation upwards continued to be recognized as qualifications for admission to the various Civil Services, since only for a few appointments, such as those in the Finance Department, was there a special Civil Service examination. The linking of the Civil Services with the universities has had the unfortunate result of overcrowding the colleges with students, in many cases of mediocre ability, and has so to some extent nullified the beneficial effect of the improved courses of study. Two other factors have also contributed to still further overcrowding : first, the continued though welcome spread of primary and secondary education, and secondly, the increasing desire for a training in the methods of science.

This increasing demand for higher education has resulted in the opening of a large number of new institutions of university rank throughout the Indian Empire. Unlike the older federal universities, the majority of these new universities have been of the unitary teaching type, as exemplified in the University of Lucknow. At the same time, the older universities have in all cases made themselves directly responsible for much of the post-graduate teaching.

In 1938 the Government of Orissa recognized the necessity of reorganizing the higher education in the Province, and it appointed a representative committee under the chairmanship of Pandit Nilkantha Das to examine the question of establishing a university in the Province. This committee presented its report* last June, and it unanimously recommends that a university of a modified affiliating type should be established. It is suggested that the university should in the first instance be purely affiliating, but that it should later be responsible for the post-graduate teaching. The administrative structure recommended for the new university is very similar to that of the University of Madras.

While many may regard it as somewhat retrograde to establish a new university of the affiliating type, it must be borne in mind that Orissa is a small and not too well-endowed province. The principal college of university standing is the Ravenshaw College at Cuttack, and this will be the

* Supplement to the Orissa Gazette, July 4, 1941. 
nucleus of the teaching university. It would, however, scarcely be economic if the teaching centres at Parlakimedi and Berhampur were to be closed down. From the figures given in the Committee's report, it is clearly not anticipated that the number of university students will be large, the estimated size of the intermediate classes in arts and science combined being about 400 students, and although there is to be a Faculty of Law, there is no provision for the teaching of medicine. It is refreshing to note that the Committee recognizes that teaching is not the sole function of a university, but that facilities should also be available for original work both in arts and science. It is not unnatural that the Committee should recommend that the post-graduate teaching in Oriya history, language and literature should receive special consideration. We trust that the new university will soon be opened and be making its own contribution to learning.

\section{ORIGIN OF LANDSCAPE FEATURES}

\section{Landscape}

As Developed by the Processes of Normal Erosion. By Prof. C. A. Cotton. Pp. xviii $+302+45$ plates. (Cambridge: At the University Press, 1941.) $21 s$. net.

$W_{\text {Britain a marked revival of interest in the }}^{\text {ITHIN the last two decades there has been in }}$ study of landscape features. The subject of geomorphology, even in its more limited scope as applied to the understanding of the surface features of the earth, has attracted new workers both from the fields of geology and geography, and fresh methods of investigation have been devised. The study of erosional geomorphology represents perhaps the most important common ground between geology and geography. In the past geologists have varied in the emphasis which they have laid on the study of 'physical geography', but until recently they have treated it mainly as part of an introductory course ; lately there has been a greater tendency to regard it as representing a more important branch of that subject, and to recognize that future progress in the investigation of landscape must depend on workers whose geological training has brought them some acquaintance with the methods of investigation needed for these fields of inquiry.

Prof. Cotton, who has written this latest volume on landscape features and their origin, is in no doubt as to the place of this study. "Notwithstanding the close relation of the study and description of the natural landscape to geography", he trusts that geologists will accept this account "of the elementary principles of geomorphology as a contribution to the literature of their science" For he stresses the faet that the developmen" of land forms has followed as a corollary of earlier geological events, while an understanding of geomorphic processes is essential for the interpretation of geological history. It may perhaps also be added that a real appreciation of the geological time-scale is necessary if landscape features are to be understood and correctly related to one another.

In this volume Prof. Cotton has not attempted to cover the whole field of land forms: he has limited himself to those features developed by the processes of "normal erosion". This he takes to include the results of atmospheric weathering (predominantly chemical) combined with downhill transportation of rock debris, mainly by rain and running water. These processes develop 'normal' landscapes. He regards as special agencies those which depend on climate, whether arid or glacial, and on marine erosion, the effects of which are confined to the land margins. While this limitation enables the author to deal more adequately with the processes which have modified the earth's surface over the widest areas, it has some disadvantages, for since the development of the present land surfaces began there have been great changes in the distribution of climatic regions, and it would be impossible to describe the landscape features of many regions, especially in the northern hemisphere, in terms of normal erosion. This is, of course, fully recognized by the author, and he has found himself compelled to refer to some of the features due to more special agencies.

Geomorphologists owe a great deal to three American pioneers, Gilbert, Powell and W. M. Davis ; Prof. Cotton acknowledges this indebtedness not merely by the dedication of his book to their memory, but also by many references to their work and opinions. This must not be taken to imply that the book is formal, or lacks up-to-date references : it presents an original and comprehen. sive account of the results of normal erosion, differing in outlook and emphasis from other books of similar scope, and dealing with the landscape of regions in all parts of the world.

Probably this wide choice of less familiar examples will be one of the most fruitful features of this volume, particularly since the illustrations lend such a distinction to the writing. For Prof. Cotton has supplied more than two hundred text. figures; most of them are new and many are beyond praise. His 'block-diagrams' are particularly successful, and convey the relation between structure and surface features in a way that will stimulate the geological student and will 